A teoria das pulsões como ontologia negativa

Vladimir Safatle

Subjetividade e cultura em Freud: ressonâncias no 'mal-estar' contemporâneo

Vincenzo di Matteo

Ontologia negativa em psicanálise: entre ética e epistemologia

Christian Ingo Lenz Dunker

Sobre o prazer excedente: de Marcuse a Aristóteles Edgardo Gutiérrez

O estatuto do inconsciente é ético Bruno de Almeida Guimarães

Da enunciação da verdade ao enunciado do gozo:

$$
\text { o mito }
$$

Cláudio Oliveira

Antígona:

heroína da psicanálise?

Phillipe van Haute

Ensaio sobre a sublimação

Tania Rivera

Observações sobre o tema da atemporalidade em Freud, Kant e Bergson Hélio Lopes

\section{Às voltas com Bento Prado}

Roberto Schwarz

Este número já estava em fase de produção quando se teve a triste notícia do falecimento do Professor Bento Prado Jr. A comissão editorial agradece a Roberto Schwarz pela generosidade com que permitiu a reprodução aqui de seu artigo, publicado na Folha de $S$. Paulo do dia 28 de janeiro de 2007.

\section{Homenagem a Bento Prado Jr. (1937 - 2007) \\ Professor Emérito da Faculdade de Filosofia, Letras e Ciências Humanas da Universidade de São Paulo}


Nos anos 60 e 70, a resistência à ditadura deu projeção extrauniversitária a alguns professores de esquerda, permitindo que mais adiante, na hora da abertura política, eles se candidatassem a cargos eletivos. O exemplo inicial em São Paulo foi Fernando Henrique Cardoso, que se elegeu suplente de senador. O salto da Faculdade de Filosofia ao parlamento, sem a passagem prévia pelo liquidificador da política profissional, criava expectativas altas e agitava os espíritos. O hábito dos estudos e da discussão, a intimidade com as ciências sociais e com o marxismo fariam diferença no governo?

Bento Prado na ocasião inventou um slogan para divertir os amigos: "Quem sabe escrever, sabe governar; Bento Prado para senador". A alegria foi geral na faculdade. A fórmula peremptória fazia rir por muitos lados. A sua inverdade clamorosa era uma piada, na verdade uma aula pela via paródica, oswaldiana ou brechtiana, sobre as presunções da oligarquia num país de alfabetização precária. Havia também o tempero biográfico. A inteligência incomum de Bento era uma unanimidade, assim como a sua inapetência para lidar com as complicações da vida prática. Além disso, ele era o descendente filósofo de uma família de fazendeiros quebrados pela crise de 29, aos quais o tom autoritário - tão bem imitado - pareceria natural. Enfim, se havia alguém que não aspirava ao mando nem queria ser mandado era ele.

A malícia das malícias entretanto não estava aí. Se o slogan fazia troça com as pretensões políticas das classes que redigem bem, ele não obstante afirmava que dentre os muitos candidatos quem sabia escrever deveras era Bento Prado ele mesmo. Sob a auto-propaganda humorística havia a estocada nos colegas menos sonhadores e este- 
tas, ou mais afeitos à política real. Atrás de tudo, a equiparação cômico-polêmica entre as Letras e a Política: se as primeiras não levam ao senado, não cedem à segunda em valor, nem se deixam abafar. Um duelo nas nuvens, mas carregado de convicção.

O fato é que Bento escrevia admiravelmente e que a sua prosa se impunha - e se impõe - à primeira vista, por razões que aliás não são fáceis de explicar. A sua frase, de caimento sempre perfeito, é ampla, muito organizada e clara, ligeiramente retórica e fora de moda, com miolo filosófico moderno. O modelo com certeza é o Drummond do período classicizante, agilizado talvez pela multiplicação malabarística de aspectos, à la Sartre e Merleau-Ponty, além de acompanhado pelo culto parnasiano da visibilidade completa, que não deixa nada na sombra. O amor da clareza - uma forma de decoro, mas sobretudo de racionalidade e universalismo - era a feição dominante da elegância buscada por Bento. Aparecia igualmente na sua maneira muito correta e atenciosa de conversar, na pronúncia de professor que não engolia sílabas nem cedia a modismos e regionalismos, e também na bela caligrafia e nos envelopes bem sobrescritados. Do ponto de vista literário, remava na contracorrente do Modernismo, que pesquisava as irregularidades brasileiras, a gramática popular, a informalidade, a forma elíptica e fragmentária, o sujeito socialmente e nacionalmente marcado.

Entretanto, o universalismo de Bento não deixava de ter a sua fisionomia social. O refinamento sintático, a visão abrangente e concatenada, o vocabulário justo, a pitada de eloqüência etc. tinham a nota senhorial - é claro que modificada pelo naufrágio histórico do senhor enquanto classe, e por um ajuste de contas filosófico com a sua figura. A seu tempo, a linguagem escoimada de brasileirismos, segura da gramática portuguesa e do Latim, terá sido um padrão de autoridade, e não só um esforço cultural. A prosa de Bento lhe conservou o arcabouço, com suas possibilidades formais e sua altura, mas obedecendo a outro sujeito.
Entre os belos traços de Bento estavam o igualitarismo radical e a ira juvenil contra o privilégio, que faziam dele um homem indiscutivelmente de esquerda. Suponho que o objeto inicial de sua revolta tenha sido a prerrogativa oligárquica, à qual o secundarista convertido ao comunismo opunha a igualdade e a justiça. Contudo, como ele logo notou, o autoritarismo e o conchavo que o indignavam na oligarquia eram a norma também no Partido Comunista, o que o colocou para sempre à margem da política prática.

A conversação com Bento era algo especial. Ele era brincalhão e farsante, mas sobretudo sério. $\mathrm{Na}$ discussão gostava de um pouco de esgrima, mas não se tratava de jogo apenas. Havia o desejo real de esclarecer as questões, e não lhe ocorria levar a melhor de qualquer jeito. A lealdade e o fair play eram parte absoluta do processo, que ultrapassava a dimensão pessoal e, meio metaforicamente, representava o interesse coletivo. $\mathrm{O}$ espírito democrático, que na política tinha pouca chance, aqui dava fruto e criava padrão. Assim, na segunda edição de seus ensaios ele publicou como posfácio uma discussão muito crítica - embora notavelmente compreensiva - de Paulo Arantes a respeito. Na mesma linha, quando saiu o meu primeiro livro Bento publicou um excelente artigo que o questionava no essencial. São procedimentos que vale a pena mencionar por não serem habituais em nosso meio.

Quando tínhamos vinte anos, Bento me fez a comunicação formal de sua repulsa pelo anti-semitismo. Era parte da consolidação de nossa amizade, e uma afirmação de suas convicções universalistas, para as quais o preconceito contra os judeus era o arquétipo de todos os preconceitos. Como eu não corria o risco de ser anti-semita, mas nem por isso tinha grande opinião de meus patrícios, a conversa tomou rumo engraçado, com o gói advogando a causa do opositor. Outra vertente de seu universalismo era o absoluto respeito pela desgraça. Tendo bastante de príncipe, ele não se achava melhor do que ninguém. Num fim de noite, quando os bares decentes já haviam fechado, ele me arrastou para um boteco atrás da Praça da Repú- 
blica, onde a sua atenção se fixou na munheca fechada e nas unhas sujas de um pobre homem adormecido, que por um bom momento resumiram para ele a angústia da existência.

Como combinar o cultor da clareza superlativa, o farsante e o notívago atormentado, que preferia que a noite não terminasse e que temia a luz do dia seguinte? Lutavam, um derrubando o outro, mas não se misturavam, e naturalmente compunham um enigma para os amigos e para ele mesmo. A poesia de Bento, que não está reunida, dá testemunho do impasse reinante no seu Laboratório de Metafísica Geral - expressão dele. Ele gostava de recitar o "Relógio do Rosário" de Drummond, especialmente os versos seguintes: “(...) E nada basta, / nada é de natureza assim tão casta // que não macule ou perca sua essência / ao contacto furioso da existência. // Nem existir é mais que um exercício / de pesquisar de vida um vago indício, // a provar a nós mesmos que, vivendo, / estamos para doer, estamos doendo.” Que falta o Bento faz!

\title{
Monique David-Ménard: \\ Deleuze ou Freud/Lacan?
}

\author{
Bento Prado Júnior
}

Professor titular de filosofia da

Universidade Federal de São Carlos (UFSCar) 